\title{
Serum and Urine Fibrinogen-Fibrin-related Antigen (F.R.-Antigen) Levels in Renal Disease
}

\author{
J. D. BRIGGS, C. R. M. PRENTICE, M. M. HUTTON, A. C. KENNEDY, G. P. McNICOL
}

deposits and to the activity of the fibrinolytic and other proteolytic enzyme systems (Johnson and Merskey, 1971). Several studies have indicated that F.R.-antigen levels may be raised in

\section{Summary}

The concentration of serum fibrinogen-fibrin-related antigen (F.R.-antigen) was measured in a group of 142 patients with various renal disorders, in 38 of whom urine F.R.-antigen was also estimated. Raised serum F.R.-antigen levels were present in $48 \%$ of the patients, with no particular preponderance in any diagnostic category apart from acute reversible intrinsic renal failure in which high levels were invariably present. Significantly-raised serum levels were also present in the patients with microangiopathic haemolytic anaemia and in those with the more severe degrees of renal impairment. Urine F.R.-antigen was increased in 34 of the 38 patients. The amount of F.R.-antigen in the urine correlated with the degree of proteinuria but not with the serum F.R.-antigen levels. The evidence relating to intravascular coagulation in renal disease is reviewed, and it is suggested that there is a high incidence of localized fibrinogen or fibrin degradation in the kidney, which is related more to factors such as the presence of uraemia and microangiopathic haemolytic anaemia rather than to the diagnostic category.

\section{Introduction}

Intravascular coagulation may involve the kidneys in diseases such as thrombotic thrombocytopenic purpura and the haemolytic uraemic syndrome. In addition, fibrin deposition in the kidney has been found by light and fluorescence microscopy in other renal diseases, in particular in proliferative glomerulonephritis and lupus nephritis (Paronetto and Koffler, 1965). There is inadequate information, however, on the extent to which fibrin formation is responsible for the renal disorder, on the mechanism by which fibrin is deposited in the kidneys, and on the types of renal disease which are associated with this process.

A sensitive method for the detection of fibrinogen or fibrin degradation appears to be estimation of serum levels of fibrinolytic degradation products (Ferreira and Murat, 1963; Merskey et al., 1966, 1967). The term fibrinogen-fibrin-related antigen (F.R.-antigen) has been introduced in place of fibrinolytic degradation products (Merskey et al., 1971) because the assay technique is based on the antigenic similarity of non-clottable fragments to fibrinogen, and it is the former term which we will use in this paper. A major source of F.R.-antigen is probably intravascular fibrin deposits and it is thought that the production of serum F.R.-antigen is related both to the extent of the fibrin

Western Infirmary, Glasgow

J. D. BRIGGS, M.B., M.R.C.P., Consultant Physician in Renal Diseases

Royal Infirmary, Glasgow

C. R. M. PRENTICE, M.D., M.R.C.P., Wellcome Senior Clinical Research Fellow

A. C. KENNEDY, M.D., F.R.C.P., Professor of Medicine

Royal Infirmary, Glasgow

M. M. HUTTON, M.B., M.R.C.PATH., Senior Registrar in Haematology

Leeds University, Leeds

G. P. MCNICOL, M.D., F.R.C.P., Professor of Medicine reversible intrinsic renal failure (acute tubular necrosis) (Stiehm and Trygstad, 1968; Wardle and Taylor, 1968; McNicol et al., 1971), and in the urine of patients with glomerulonephritis (Clarkson et al., 1971), and rejecting renal transplants (Braun and Merrill, 1968; Clarkson et al., 1970a). The significance of raised F.R.-antigen in these diseases can be assessed only by comparing their concentration with types of renal disease in which fibrin deposition is not thought to play a major part in pathogenesis. Accordingly, we havemeasured serum F.R.-antigen in 142 patients with a wide range of renal disorders. Also urine F.R.-antigen was estimated in 38 of these patients.

\section{Patients and Methods}

One hundred and forty-two patients with renal disorders were studied (77 male and 65 female. Mean age was 37, range 4 to 77 years). Patients were randomly selected from two sources, a group of hospital inpatients and those attending the renal clinic. In 59 of the 142 patients duplicate serum samples were obtained within a 48-hour period for measurement of F.R.-antigen, and the result expressed as a mean of the two values. In only five of the 59 patients did the two results differ by more than one tube dilution. In the remaining 83 a single serum sample was obtained. Blood samples for F.R.-antigen estimation were collected in $0.04 \%$ tranexamic acid and clotted for four hours at room temperature before separation of the serum. F.R.-antigen was measured by the tanned red cell haemagglutination inhibition technique of Merskey et al. (1966). The results were expressed as $\mu \mathrm{g} / \mathrm{ml}$, and the upper limit of normal was found to be $4 \mu \mathrm{g} / \mathrm{ml}$. Statistical analysis was carried out by the $\chi^{2}$ method in which the number of normal and raised serum F.R.antigen levels in the various groups were compared.

The urine samples for F.R.-antigen assay were collected for a 24-hour period. Initially tranexamic acid or soya bean trypsin inhibitor was added to the collection bottles. Later this procedure was omitted as it was found in a series of duplicate samples with and without the addition of a fibrinolytic inhibitor that there was no appreciable difference in the F.R.-antigen levels. The urine was concentrated 40 -fold by ultrafiltration in an Amicon 52 ultrafiltration cell (Amicon, N. V., The Hague, Holland) with a UM-2 membrane, and the F.R.-antigen concentration was measured in the same way as the serum samples. The results were expressed as $\mathrm{mg} / 24 \mathrm{hr}$, and we found the upper limit of normal in healthy subjects to be $0.1 \mathrm{mg}$.

The type of renal disease was confirmed where necessary by radiological techniques or renal biopsy with the exception of seven patients who were classified solely on clinical grounds as having chronic renal failure. Uraemia was defined as a blood urea of more than $100 \mathrm{mg} / 100 \mathrm{ml}$, and malignant hypertension as the presence of fresh haemorrhages, exudates, and/or papilloedema in both fundi. Microangiopathic haemolytic anaemia (M.H.A.) was diagnosed only when there was widespread red cell fragmentation on the peripheral blood film, burr cells not being counted as fragmented cells. Serum $\beta_{1} c$ globulin levels were measured by the radial immunodiffusion method using a specific antiserum. Urine protein was measured by the Biuret technique and expressed as $\mathrm{g} / 24 \mathrm{hr}$. 


\section{Results}

\section{SERUM F.R.-ANTIGEN}

The serum F.R.-antigen levels related to the different diagnostic groups are shown in Fig. 1. In most of the groups there was a wide range of results from normal to moderate rises and in 68

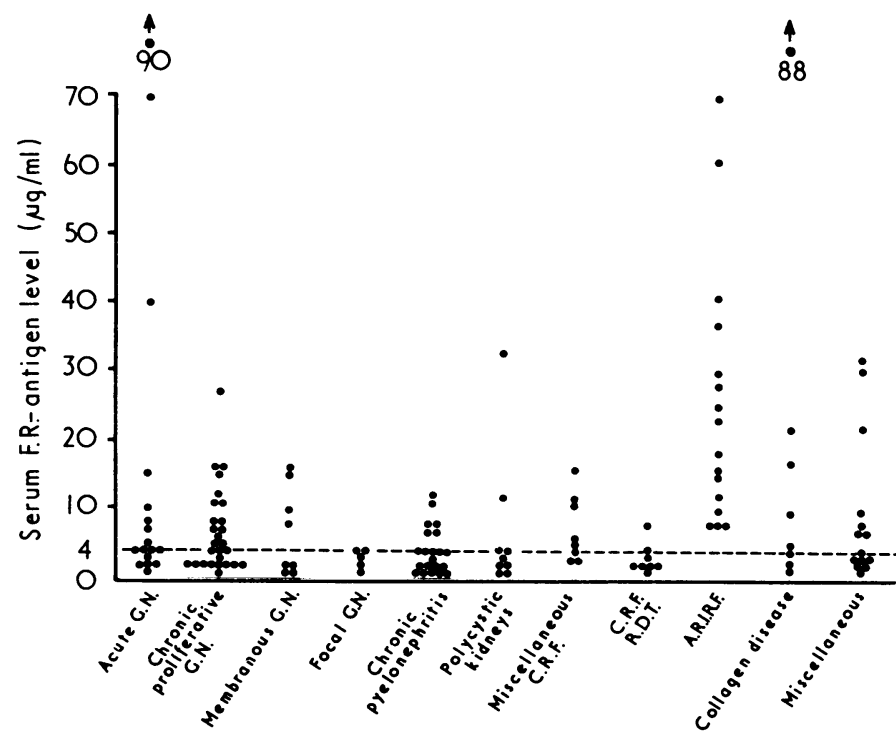

FIG. 1-Serum F.R.-antigen levels in different diagnostic groups. G.N. = Glomerulonephritis. C.R.F. = Chronic renal failure. R.D.T. = Regular dialysis therapy. A.R.I.R.F. = Acute reversible intrinsic renal failure.

of the 142 patients ( $48 \%$ ) raised values were found. The only diagnostic group which differed from the remainder in the percentage of raised values was acute reversible intrinsic renal failure $(P<0.001)$, in which all patients had high serum F.R.antigen levels. About half of the patients with diffuse forms of glomerulonephritis had raised levels, while in most patients with chronic pyelonephritis, polycystic kidneys, focal glomerulonephritis, and those on regular haemodialysis the levels were normal.

Relation of Microangiopathic Haemolytic Anaemia (M.H.A.) to Diagnosis

\begin{tabular}{|c|c|c|c|c|c|}
\hline \multicolumn{4}{|l|}{ Diagnosis } & \multirow{2}{*}{$\begin{array}{c}\begin{array}{c}\text { Patients } \\
\text { with } \\
\text { M.H.A. }\end{array} \\
10 \\
3 \\
2 \\
2 \\
1\end{array}$} & \multirow{2}{*}{$\begin{array}{c}\begin{array}{c}\text { Patients } \\
\text { withou } \\
\text { M.H.A }\end{array} \\
9 \\
13 \\
5 \\
13 \\
0\end{array}$} \\
\hline $\begin{array}{l}\text { Malignant hypertension* } \ldots \\
\text { Acute glomerulonephritis } \\
\text { Collagen disease } \\
\text { Acute reversible intrinsic renal failure } \\
\text { Haemolytic uraemic syndrome } \quad . . \\
\text { Ha }\end{array}$ & $\begin{array}{l}\cdots \\
\cdots \\
\cdots\end{array}$ & $\begin{array}{l}\ldots \\
\cdots \\
\cdots\end{array}$ & $\begin{array}{l}\ldots \\
\cdots \\
\cdots\end{array}$ & & \\
\hline \multicolumn{4}{|c|}{ Total } & 18 & 40 \\
\hline
\end{tabular}

* The underlying diseases in these 19 patients were: acute glomerulonephritis (1), chronic proliferative glomerulonephritis (4), membranous glomerulonephritis (1) essential hypertension (4), miscellaneous (2).

M.H.A. was present in 18 patients (see Table), in 16 of whom the serum F.R.-antigen level was raised. All these patients were uraemic (blood urea $>100 \mathrm{mg} / 100 \mathrm{ml}$ ), and in comparison with the remaining 68 uraemic patients they had a significantly higher incidence of raised F.R.-antigen levels $(P<0.02)$ (Fig. 2).

Nineteen patients had malignant hypertension, of whom 10 had M.H.A. in addition. The 10 patients with both malignant hypertension and M.H.A. had significantly higher F.R.-antigen levels than the nine hypertensive patients without M.H.A. $(P<0.05)$ (Fig. 3). However, the patients with malignant hypertension as a group did not have a higher incidence of raised F.R.-antigen than the remaining uraemic patients.

A higher proportion of the 86 uraemic patients had raised serum F.R.-antigen levels than the 56 in the non-uraemic group
( $P<0.001)$. All the patients with M.H.A. and with acute reversible intrinsic renal failure fell within the uraemic group. Even when these two categories, which were known to have high F.R.-antigen levels, were excluded from analysis the remaining 52 uraemic patients still had a higher proportion of raised serum F.R.-antigen levels ( 29 out of 52 ) than the non-uraemic patients (11 out of 56) $(P<0.001)$.

The urine F.R.-antigen levels for the 38 patients studied, shown in Fig. 4, are divided into five diagnostic categories. While some of the patients had several estimations performed the results plotted refer to the initial 24-hour sample which was collected at the same time as withdrawal of blood for serum F.R.-antigen measurement. In some patients with stable renal lesions widely differing urine F.R.-antigen levels were obtained within a period of three to four days. Urine F.R.-antigen excretion was raised in most patients but there was no correlation with the diagnosis. Also, there was no correlation between the concentration of urine F.R.-antigen and serum F.R.-antigen, blood urea, or the presence of M.H.A. There was, however, a

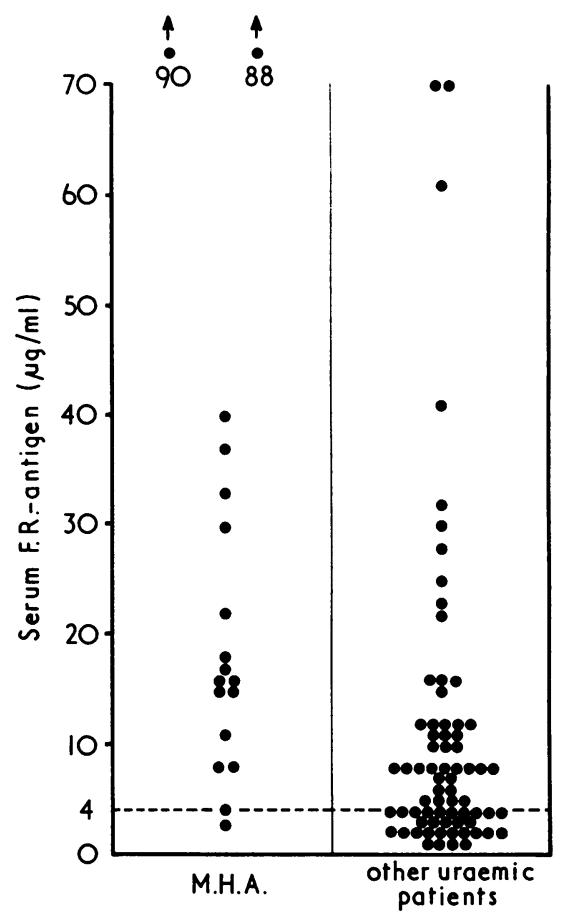

FIG. 2-Comparison of serum F.R.-antigen levels between patients with M.H.A. and remaining uraemic patients (all patients with M.H.A. were uraemic). Incidence of raised levels differed significantly between the two groups $(\dot{P}<0.02)$.

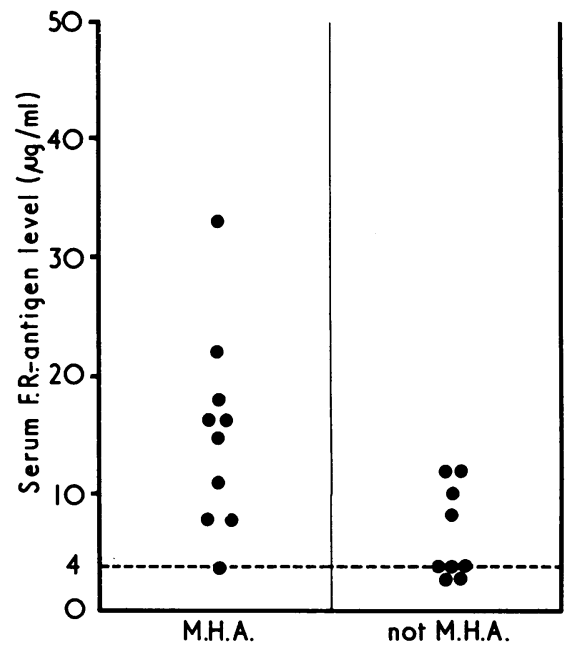
FIG. 3-Comparison in patients with malignant hypertension of serum F.R.raised levels differed significantly $(P<0.05)$. 


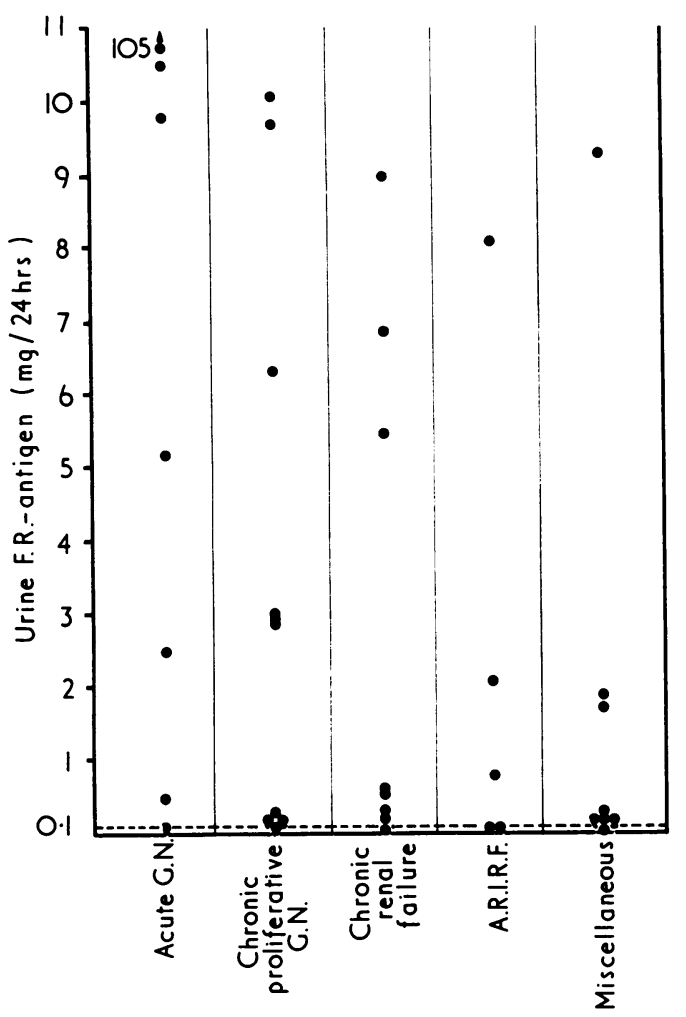

FIG. 4-Amounts of urinary F.R.-antigen in different diagnostic groups. G.N. = Glomerulonephritis. A.R.I.R.F. = Acute reversible intrinsic renal failure.

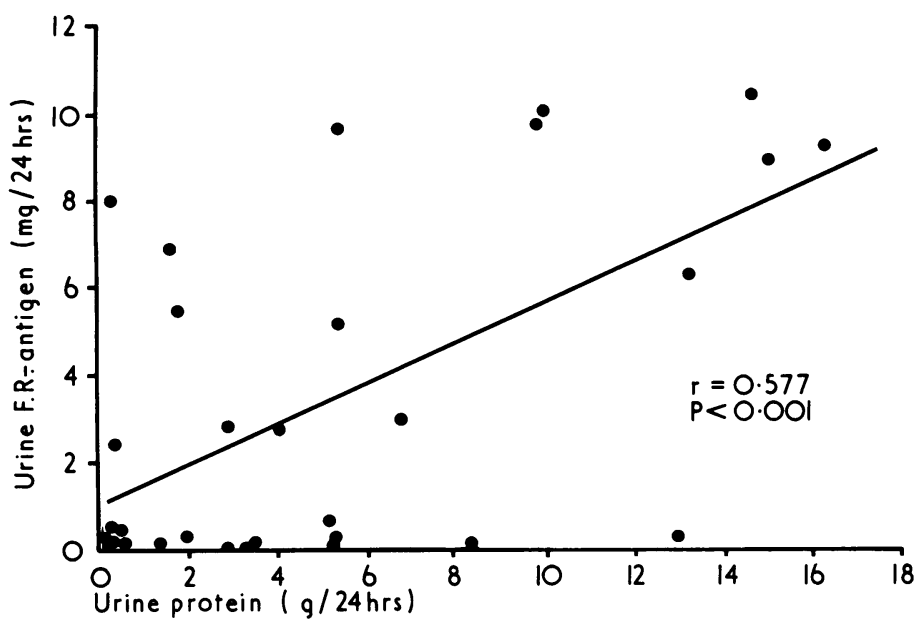

FIG. 5-Urine F.R.-antigen related to proteinuria. $(y=1 \cdot 13+0.46 x)$.

correlation between F.R.-antigen and the urine protein excretion ( $\mathrm{r}=0.577, \mathrm{P}<0.001)$ (Fig. 5).

\section{Discussion}

We found raised levels of serum F.R.-antigen in about half of a group of 142 patients with renal disease. These findings extend our earlier observations (McNicol et al., 1971) and confirm that only patients with acute reversible intrinsic renal failure had a higher incidence of raised serum F.R.-antigen levels in comparison with the other diagnostic categories. Intravascular coagulation within the glomeruli has been suggested as a factor in the pathogenesis of the acute renal failure resulting from renal ischaemia, in view of the finding of intraglomerular fibrin deposition (Clarkson et al., 1970b), abnormalities in the coagulation and fibrinolytic systems, raised levels of serum F.R.-antigen (Wardle and Taylor, 1968), and the excretion of urine F.R.antigen during the recovery phase (Clarkson et al., 1970b). Raised levels of serum F.R.-antigen, however, occur commonly in the clinical situations which may precede acute renal failure such as shock (Wardle and Taylor, 1968), pre-eclampsia (Bonnar et al., 1971), and systemic complications after surgery (Wood et al., 1972), and the high serum F.R.-antigen levels may be related more to proteolysis of intravascular fibrin associated with the preceding illness than to the renal failure itself.

Stiehm and Trygstad (1968), in a series of 124 children, described three groups of renal diseases according to the serum F.R.-antigen level. Firstly, those with generalized intravascular coagulation such as the haemolytic-uraemic syndrome; secondly, those with localized intravascular coagulation such as acute and chronic glomerulonephritis; and thirdly, those without intravascular coagulation - for instance, nephrosis and urinary tract infection. In their patients, the incidence of raised serum F.R.antigen levels in acute and chronic glomerulonephritis was about $80 \%$. By contrast, Clarkson et al. (1971), presumably in a mainly adult population, reported raised serum levels in only $36 \%$ of patients with proliferative glomerulonephritis, with a preponderance of raised levels in those whose renal lesion was thought to be active. The present results fall midway between these two series in that about $50 \%$ of our patients with both acute and chronic proliferative glomerulonephritis had raised serum F.R.-antigen levels. Our finding of an equal incidence of raised levels in acute and chronic glomerulonephritis is at variance with the suggestion of Clarkson et al. (1971) that the serum F.R.-antigen concentration correlates with the degree of activity of the disease. The fact that half of the present patients with membranous glomerulonephritis, a condition not usually associated with the criteria of "activity" quoted by Clarkson et al. (1971), had raised levels argues also against their concept.

The association between raised serum F.R.-antigen and a wide variety of renal diseases could be explained on the basis that there is an increased tendency towards fibrin deposition and subsequent proteolytic digestion in them. Alternatively, the raised serum F.R.-antigen levels might reflect local intrarenal fibrin deposition as a result of endothelial damage. Fibrinoid change in small blood vessels is seen not only in malignant hypertension (Kincaid-Smith et al., 1958) but also in other conditions, including polyarteritis (Pickering, 1961), and there is evidence to suggest that the fibrinoid material is composed mainly of fibrin (Lendrum, 1964; Ooneda et al., 1965). There was a significant rise of serum F.R.-antigen in the patients with M.H.A., suggesting that they had a greater degree of fibrin deposition than patients without this complication. Brain et al. (1962) found an association between M.H.A. and vascular lesions in renal diseases, and the occurrence of M.H.A. in 10 of the 19 patients with malignant hypertension in this series supports previous findings (Linton et al., 1969) that M.H.A. is associated with increased fibrin deposition, possibly as a result of endothelial damage or as a result of the release of thromboplastic substances from the fragmented red cells. An alternative explanation is suggested by the findings of Charm and Wong (1970) who showed that fibrinogen undergoes degradation owing to shearing within the circulation. Accelerated fibrinogen degradation because of increased shearing within the damaged renal microcirculation could lead to the appearance of circulating non-clottable fibrinogen fragments without the previous deposition of fibrin in the vessels.

There was a significantly higher incidence of raised serum F.R.-antigen levels in the uraemic patients than in the nonuraemic group. This higher incidence of raised serum F.R.antigen persisted even after exclusion of the patients with acute reversible intrinsic renal failure who were all uraemic and had consistently high serum F.R.-antigen. The influence of uraemia on serum F.R.-antigen could be partly explained by the fact that the uraemic patients would have a greater degree of glomerular and renal vascular damage. Alternatively, the possibility that cellular damage associated with uraemia might release substances such as proteases or cathepsins which in turn digest fibrinogen cannot be excluded (Johnson and Merskey, 1971). This sequence of events would explain the finding that raised serum F.R.-antigen levels are sometimes associated with evidence of decreased fibrinolytic activity, which is known to 
occur in renal disease (McNicol et al., 1965; Wardle et al., 1970; Prentice et al., 1972), although Pandolfi et al. (1970) showed that the activator content of renal vessels is independent of the degree of uraemia.

Raised levels of urine F.R.-antigen were present in 34 of 38 patients but did not correlate with the type of renal disease, serum F.R.-antigen level, or severity of the renal failure. We found, as did Clarkson et al. (1971) that there were wide variations in the amounts of urine F.R.-antigen from day to day in the same patient. The lack of correlation between the serum and urine F.R.-antigen levels, and the presence in 14 patients of raised urine F.R.-antigen together with normal serum levels supports previous evidence that urine F.R.-antigen appears as a result of local fibrinogen or fibrin degradation in the kidney (Humair et al., 1969). On the other hand, correlation between the amounts of F.R.-antigen and of protein in the urine suggests that part of the urine F.R.-antigen concentration is derived by glomerular filtration. Although raised urinary F.R.-antigen has been described previously in a variety of renal diseases (Rayner et al., 1969; Clarkson et al., 1970b), the wide range of results obtained in diagnostic groups precludes any use as a diagnostic aid, except possibly in the detection of incipient renal transplant rejection (Braun and Merrill, 1968; Carlsson et al., 1970; Clarkson et al., 1970a). Additionally, serial assays may be of use as a prognostic guide (Clarkson et al., 1971)

An important problem is whether F.R.-antigen is an almost irrelevant by-product of basic renal disease which will continue on its way uninfluenced by therapeutic measures, or whether the immediate mechanism which produces F.R.-antigen is central to the pathogenesis of the disease. It might be that heparin, for example, could control some of the manifestations of renal disease without in any way influencing the fundamental downhill progression. Although initial results of anticoagulant therapy in glomerulonephritis in experimental animals (Vassalli and McCluskey, 1964; Halpern et al., 1965) and in man (KincaidSmith et al., 1970) have been encouraging, further information, preferably based on a controlled clinical trials, is urgently needed.

We are grateful to Mrs. Christine Pidgeon for invaluable technical help. G.R.M.P. is in receipt of a grant from the Wellcome Trust.

Requests for reprints should be addressed to Dr. J. D. Briggs, Renal Unit, Western Infirmary, Glasgow, G11 6NT.

\section{References}

Bonnar, J., McNicol, G. P., and Douglas, A. S. (1971). British Medical Fournal, 2, 12

Brain, M. C., Dacie, J. V., and Hourihane, D.O'B. (1962). British fournal of

Braun, W. E., and Merrill, J. P. (1968). New England fournal of Medicine, 278, 1366.

Carlsson, S., Hedner, U., Nilsson, I. M., Bergentz, S. E., and Ljungqvist, V. (1970). Transplantation, 10, 366

Charm, S. E., and Wong, B. L. (1970). Science, 170, 466.

Clarkson, A. R., Morton J. B., and Cash, J. D. (1970a). Lancet, 2, 1220. Clarkson, A. R., MacDonald, M. K., Fuster, V., Cash, J. D., and Robson, J. S. (1970b). Quarterly fournal of Medicine, 39, 585.

Clarkson, A. R., MacDonald, M. K., Petrie, J. J. B., Cash, J. D., and Robson, J. S. (1971). British Medical fournal, 3, 447.

Ferreira, H. C., and Murat, L. G. (1963). British fournal of Haematology, 9 299.

Halpern, B., Milliez, P., Lagrue, G., Fray, A., and Morard, J. C. (1965). Nature, 205, 257.

Humair, L., Potter, E. V., and Kwaan, H. C. (1969). Fournal of Laboratory and Clinical Medicine, 74, 60.

Johnson, A. J., and Merskey, C. (1971). Scandinavian fournal of Haematology, Suppl. No. 13, p. 87.

Kincaid-Smith, P., McMichael, J., and Murphy, E. A. (1958). Quarterly fournal of Medicine, 27, 117.

Kincaid-Smith, P. Laver, M. C., and Fairley, K. F. (1970). Medical fournal of Australia, 1, 145.

Lendrum, A. C. (1964). British fournal of Surgery, 51, 723.

Linton, A. L., et al. (1969). Lancet, 1, 1277.

McNicol, G. P., Barakat, A. A., and Douglas, A. S. (1965). Scottish Medical fournal, 10, 189.

McNicol, G. P., Prentice, C. R. M., Briggs, J. D., and Pidgeon, C. (1971) Scandinavian fournal of Haematology, Suppl. No. 13, p. 329.

Merskey, C., Kleiner, G. J., and Johnson, A. J. (1966). Blood, 28, 1

Merskey, C., Johnson, A. J., Kleiner, G. J., and Wohl, H. (1967). British Fournal of Haematology, $12,528$.

Merskey, C., Lalezari, P., and Johnson, A. J. (1971). Scandinavian fournal of Haematology, Suppl. No. 13, p. 83.

Ooneda, G., et al. (1965). Angiology, 16, 8

Pandolf, M., Bergentz, S. E., Claes, G., and Ljungqvist, V. (1970). VI Conference of the European Society for Microcirculation, Aalborg, Denmark.

Paronetto, F., and Koffler, D. (1965). Fournal of Clinical Investigation, 44, 1657.

Pickering, G. P. (1961). Nature of Essential Hypertension, pp. 7, 99. New York, Grune and Stratton.

Prentice, C. R. M., Briggs, J. D., Kennedy, A. C., and McNicol, G. P. (1972). Unpublished observations.

Rayner, H., Paraskevas, F., Israels, L. G., and Israels, E. D. (1969). Fournal of Laboratory and Clinical Medicine, 74, 586.

Stiehm, E. R., and Trygstad, C. W. (1968). American fournal of Medicine, 46, 774.

Vassalli, P., and McCluskey, R. T. (1964). Annals of the New York Academy of Sciences, 116, 1052.

Wardle, E. N., and Taylor, G. (1968). Fournal of Clinical Pathology, 21, 140 Wardle, E. N., Menon, I. S., and Rastogi, S. P. (1970). British Medical Fournal, 2, 260.

Wood, E. H., Prentice, C. R. M., and McNicol, G. P. (1972). Lancet, 1, 166.

\section{MEDICAL MEMORANDA}

\section{Quinine Amblyopia Treated with Stellate Ganglion Block}

\section{J. L. KENNERLEY BANKES, J. A. HAYWARD, M. B. S. JONES}

British Medical fournal, 1972, 4, 85-86

Quinine overdosage is uncommon nowadays in medical practice.

The syndrome of cinchonism is, however, well described, the most dangerous component of which is loss of vision. We report a case of quinine amblyopia which responded dramatically to stellate ganglion block and the findings of almost a year's follow-up.

St. Mary's Hospital, London W.2

J. L. KENNERLEY BANKES, M.B., F.R.C.S., Consultant Ophthalmic

J. A. HAYWARD, M.B., B.chIR., House Physician, Medical Unit (Present address: Hammersmith Hospital, London W.12)

M. B. S. JONES, M.B., M.R.C.P., Registrar, Medical Unit (Present appointment: Senior Registrar, Edgware General Hospital, Edgware, Middlesex)

\section{Case History}

An unemployed 16-year-old girl took about $15300 \mathrm{mg}$ tablets of quinine sulphate $(4.5 \mathrm{~g})$ on the evening of 20 September 1970. They had been prescribed for her mother's night cramps and were swallowed as a suicide gesture after a family row. She vomited several times that night and found by the following morning she was virtually blind though otherwise perfectly well. She was admitted to St. Mary's Hospital, London, at noon on 21 September.

On examination she was fully conscious, with regular pulse and normal blood pressure. The only abnormal physical findings were ocular. She was only just able to distinguish light from dark; the pupils were widely dilated and just reacted to light. Her fundi appeared entirely normal.

\section{MANAGEMENT}

Forced diuresis was begun after stomach washout. Initial investigations showed a normal haematological picture, urea, and electroytes. The serum quinine level was $7 \cdot 2 \mathrm{mg} / 1$. Inhalation of amyl nitrite produced flushing of the conjunctivae but no subjective visual improvement or fundal changes. Three hours after admission bilateral stellate ganglion block was performed (Dr. K. Herdman). A dose of $10 \mathrm{ml}$ of $5 \%$ Marcain was injected each side. 